\title{
A STUDY TO ANALYZE THE SELF-DISCHARGE CHARACTERISTICS OF BRYOPHYLLUM PINNATUM LEAF FUELED BPL TEST CELL
}

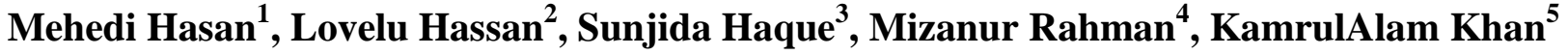 \\ ${ }^{1}$ Lecturer, Department of Electrical and Electronic Engineering, City University, Dhaka, Bangladesh \\ ${ }^{2}$ PhD Researcher, Department of Physics, Jahangirnagar Univeristy, Dhaka, Bangladesh \\ ${ }^{3}$ Lecturer, Department of Electrical and Electronic Engineering, City University, Dhaka, Bangladesh \\ ${ }^{4}$ Post-Graduate Student, Department of Physics, Jagannath Univeristy, Dhaka, Bangladesh \\ ${ }^{5}$ Professor, Department of Physics, Jagannath Univeristy, Dhaka, Bangladesh
}

\begin{abstract}
The leaf of Bryophyllumpinnatum plant contains some organic acids. A technique has been developed to extract electrical energy from this leaf. A cell fueled by Bryophyllum pinnatum is called BPL cell. Our study showed that, this kind of cell is capable for LED bulb lightning, tuning radios and even charging mobiles. So, from this BPL cell, people at the off-grid region can get some electricity and can get benefitted a lot. In this paper, we shall try to show our work on the self-discharge characteristic of the BPL test cell in a new way.
\end{abstract}

Keywords: BPL cell, Biomass, Electricity for off-grid people.

\section{INTRODUCTION}

In batteries, self-discharge is an occurrence caused by opportunistic reactions, such as corrosion, where the inner chemical reactions decrease the deposited charge of the battery although there is no connection between the terminals. As the storage charge reduces with time, as a result of self-discharge, the shelf-life of batteries is also decreases which causes them to primarily have less than a full charge when actually put to use. The rate of decreasing of storage energy depends on the cell chemistry and the temperature [1]. Normally, the discharge direction is related to the equilibrium of electrode reactions, since, thermodynamically, the discharged state is more spontaneous. The rate of self-discharge (loss of capacity [charge] when no external load is applied) of the voltaic cell is fairly rapid. Further energy loss may arise as a result of discharge during which insulating products may form or the electrolyte may be consumed. Therefore, shelf-life is limited by factors related to both nonuse and normal usage. But the rate of self-discharge can be reduced significantly by incorporating certain design features[2].

Table -1: The typical shelf-life for some primary cells [3].

\begin{tabular}{|l|l|}
\hline Zinc Carbon (Leclanché) & 2 to 3 years \\
\hline Alkaline & 5 years \\
\hline Lithium & 10 years or more \\
\hline
\end{tabular}

Table -2: Typical self-discharge rates for common rechargeable cells are given below [3].

\begin{tabular}{|l|l|}
\hline Nickel Cadmium & $10 \%$ per month \\
\hline Nickel Metal Hydride & $30 \%$ per month \\
\hline Lithium & $5 \%$ to $10 \%$ per month \\
\hline NiMH batteries & $1.25 \%$ per month \\
\hline Nickel Cadmium & $10 \%$ per month \\
\hline
\end{tabular}

\section{BRYOPHYLLUM PINNATUM LEAF AS A} \section{SOURCE OF BIOMASS ENERGY}

The scientific name- Bryophyllum pinnatum, also known as the Air Plant, Life Plant, Miracle Leaf, Green Mother of Millions and Goethe Plant is a succulent plant native to Madagascar, which is a popular houseplant and has become naturalized in temperate regions of Asia, the Pacific and Caribbean. It is distinctive for the profusion of miniature plantlets that form on the margins of its leaves, a trait it has in common with the other members of the genus Bryophyllum. Scientific classification of Bryophyllum pinnatum is given below[7]-

\begin{tabular}{|l|l|}
\hline Kingdom: & Plantae \\
\hline Division: & Angiosperms \\
\hline Class: & Eudicots \\
\hline Order: & Saxifragales \\
\hline Family: & Crassulaceae \\
\hline Genus: & Bryophyllum \\
\hline Species: & B. pinnatum \\
\hline
\end{tabular}

Some organic acids, such as, Amino acid, Syringic acid, Caffeic acid, Ascorbic acid, Mallic acid, Iso-citric acid etc. can be found in the leaf of Bryophyllum pinnatum $[4][5][6][8][9][10]$. These organic acids are used as electrolytes in our test cell with copper and zinc as electrodes.

\section{EXPERIMENTAL SET-UP OF A TEST BPL}

\section{CELL}

The plant grows almost everywhere even in the cement, watery lands. We have collected our specimen from the 
countryside. After removing the dirt from the leaves by washing and then drying, we blended by adding some water. And we also added $\mathrm{CuSO}_{4} \cdot 5 \mathrm{H}_{2} \mathrm{O}$ as secondary salts. After making the sap for the experiment, we've calculated the percentage of each specimen and found $85.308 \%$ BPL, $14.214 \%$ water and $0.4739 \% \mathrm{CuSO}_{4} .5 \mathrm{H}_{2} \mathrm{O}$ approximately.

As the zinc and copper sheets are available and cheaper than other materials, we used those in our technique of electricity generation. The dimensions of electrodes are given below-

Table -3: Properties and dimension of anode and cathode.

\begin{tabular}{|l|l|l|}
\hline Properties & Anode & Cathode \\
\hline Element & Zinc & Copper \\
\hline Average Height & $105.56 \mathrm{~mm}$ & $105.39 \mathrm{~mm}$ \\
\hline Average Length & $53.12 \mathrm{~mm}$ & $53.26 \mathrm{~mm}$ \\
\hline Average Thickness & $0.71 \mathrm{~mm}$ & $0.17 \mathrm{~mm}$ \\
\hline Average Mass & $27.71 \mathrm{gm}$ & $6.77 \mathrm{gm}$ \\
\hline
\end{tabular}

To keep the study, continue, we used a voltammeter (a test cell), which is rectangular in shape and made of glass. The cell was $10 \mathrm{~cm}$ long, width was $6 \mathrm{~cm}$ and height $12 \mathrm{~cm}$, had an inner volume of $720 \mathrm{~cm}^{3}$. We called this a testunit cell because for producing larger energy, we use the cell whose several parameters and dimensions are integral multiple of this kind of cell.

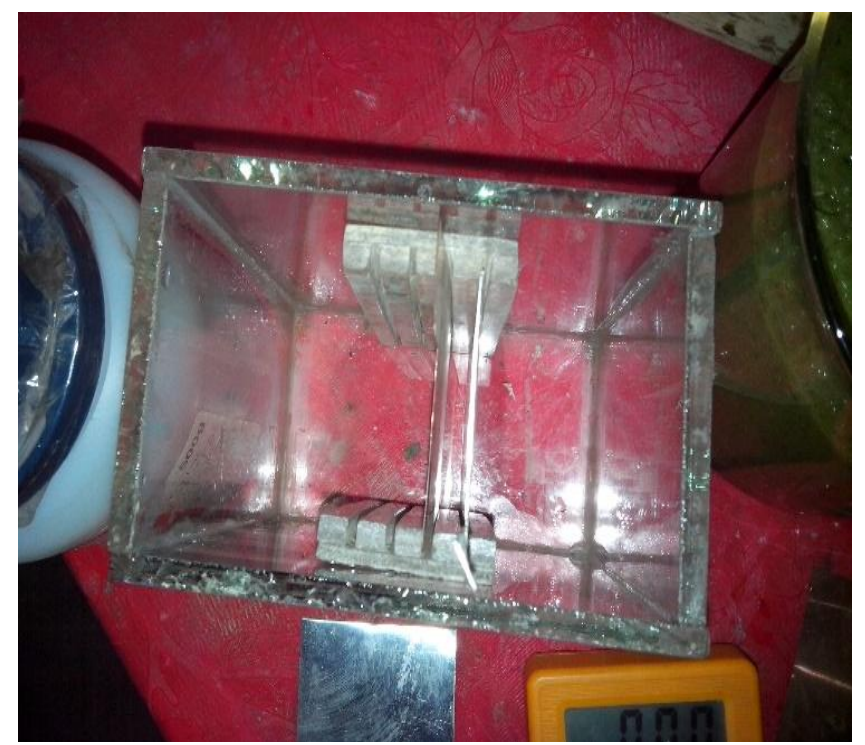

Fig -1: The voltammeter.

We used four zinc plates as one anode and two copper plates as one cathode of same dimensions. That means the anodic surface area is twice than the cathodic surface area in the test cell. The distance between two electrodes were $5 \mathrm{~mm}$ and kept constant. All the electrodes were immersed 120 mm deep in the sap in the test cell. That depth was kept fixed throughout the experiment. At the upper part of the sap, i.e. glass container, a $\mathrm{pH}$ meter was set up to get the $\mathrm{pH}$ reading incessantly. A digital ammeter and a voltmeter were used to measure the Short Circuit Current and Open Circuit Voltage. While talking the reading, we found that the values of open circuit voltage and short circuit current were changing continuously. So, we've taken the values which were found stable for 3-5 seconds.

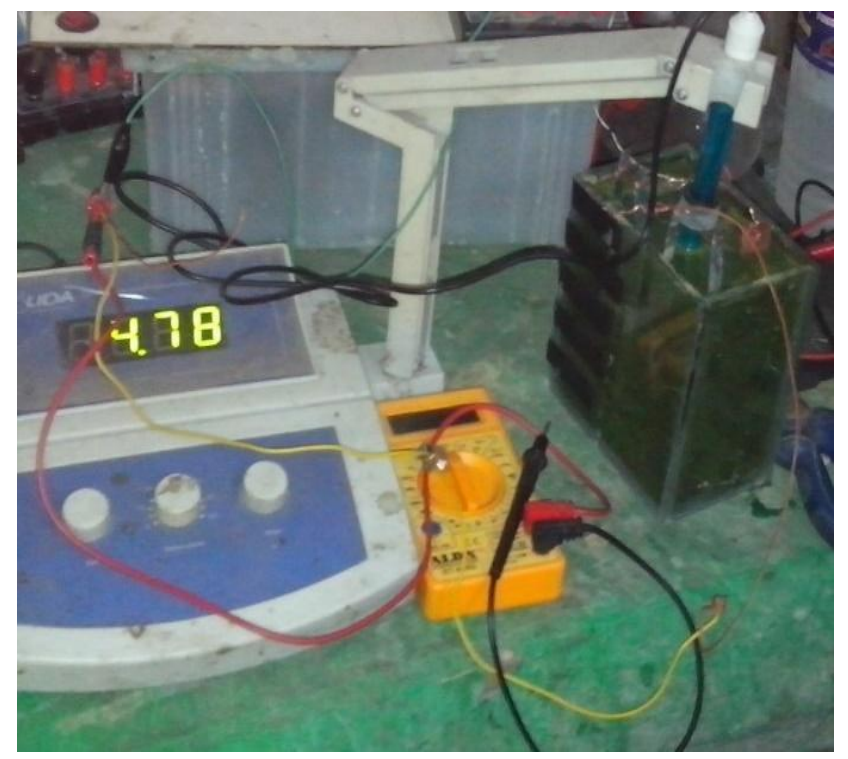

Fig -2: An experimental set-up of studying the selfdischarge characteristics of BPL cell [8].

Trough out our study, we used a term named "Cycle" which is the number of uses of same sap for several periods. Cycle1 means newly made sap was used for the study. When the $\mathrm{pH}$ of the sap becomes 7.00, we took the sap from the glass container to a beaker and used a small rod to stair the sap and then again put that in the glass container for further study. Thus, we a new cycle, called Cycle-2 was investigated. We also continued this for Cycle-3. [A similar set-up and procedure were followed while determining the approximate electrical energy of BPL] [8].

\section{RESULTS}

The variation of short circuit current,open circuit voltage and $\mathrm{pH}$ with time in different cycles are given below. 


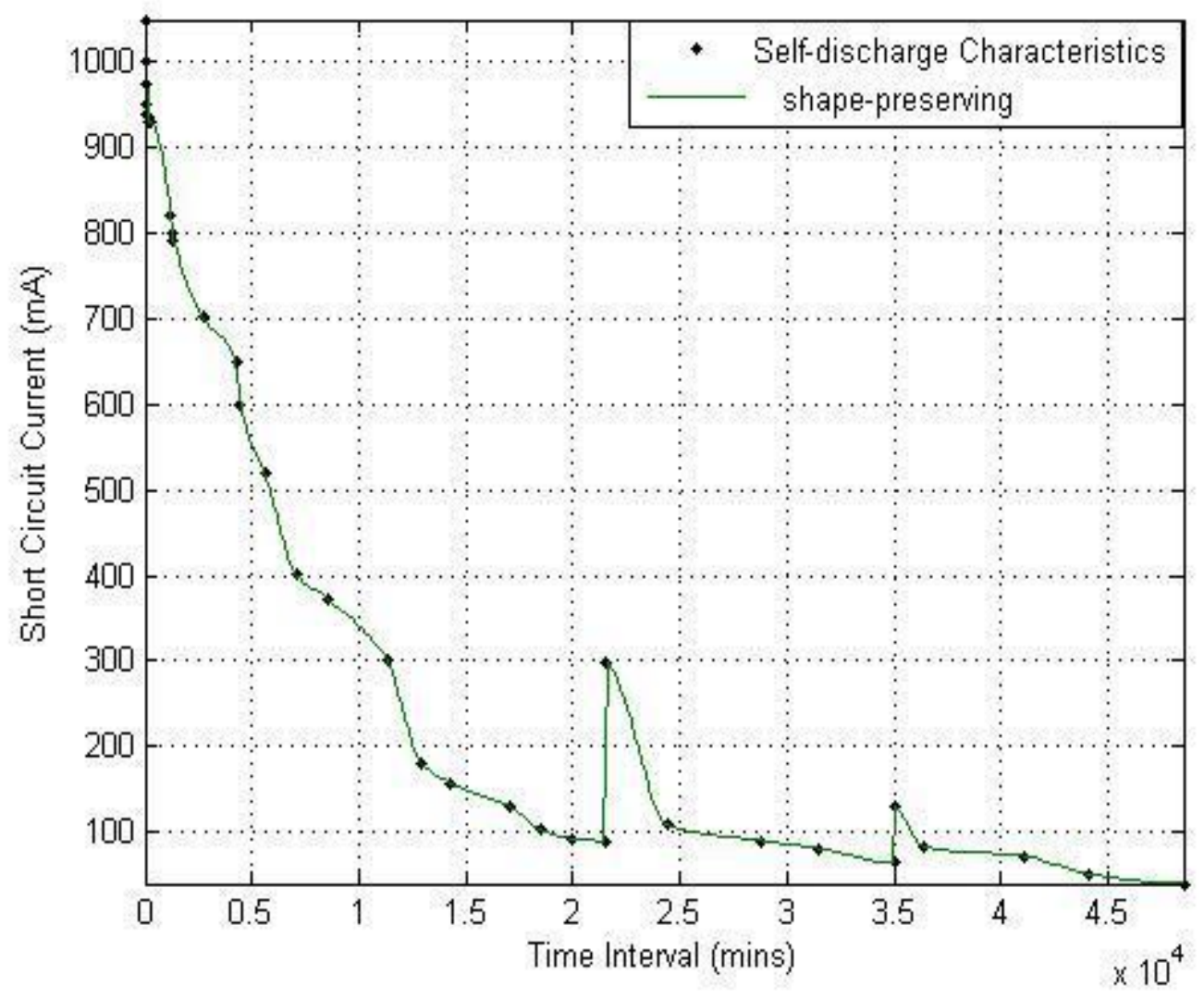

Fig -3: Short Circuit Current Vs Time graph for all three cycles.

In the Fig-3, we can see the three peaks, where the values of short circuit currents are higher to their adjacent values.

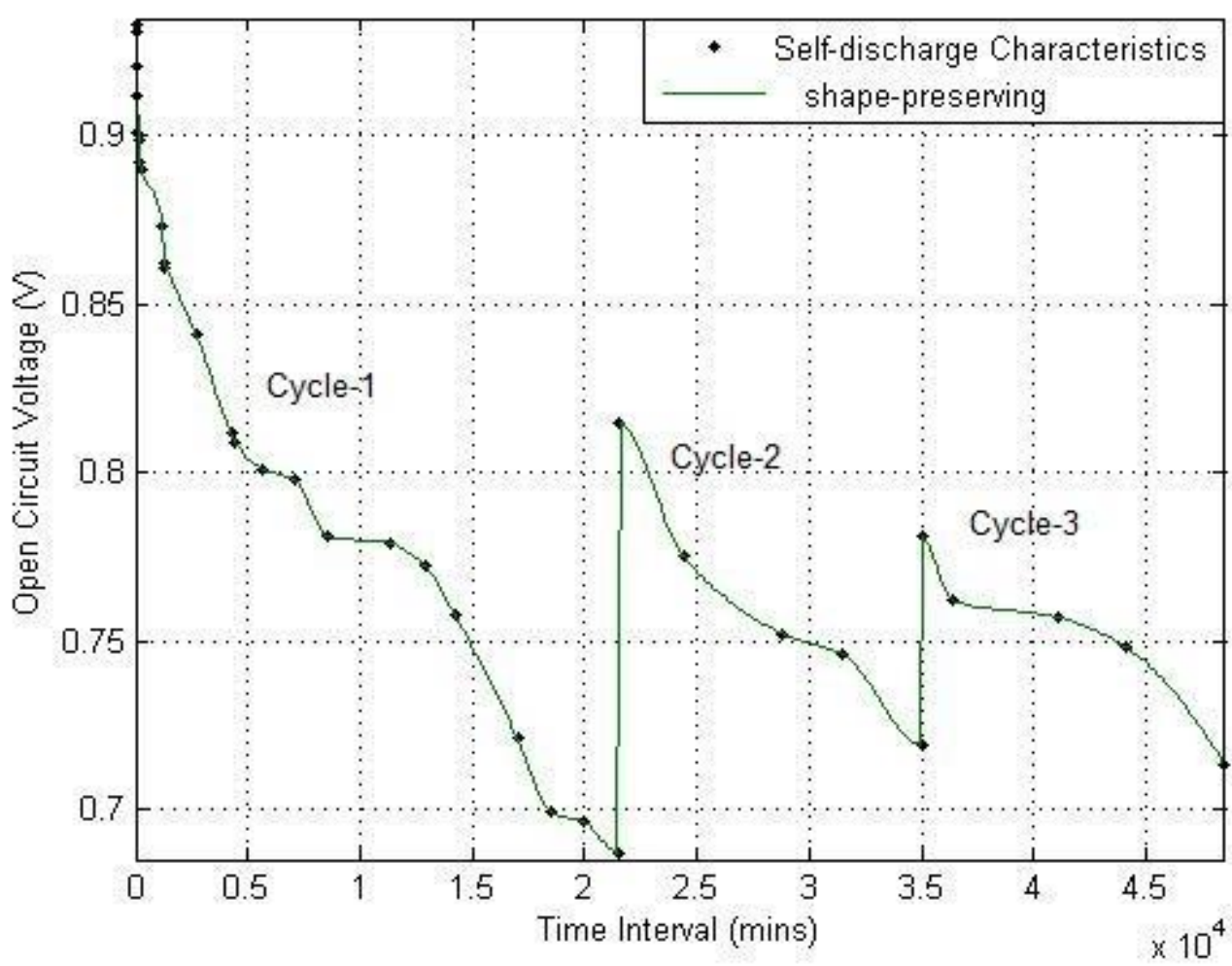

Fig -4: Open Circuit Voltage Vs Time graph for all three cycles. 


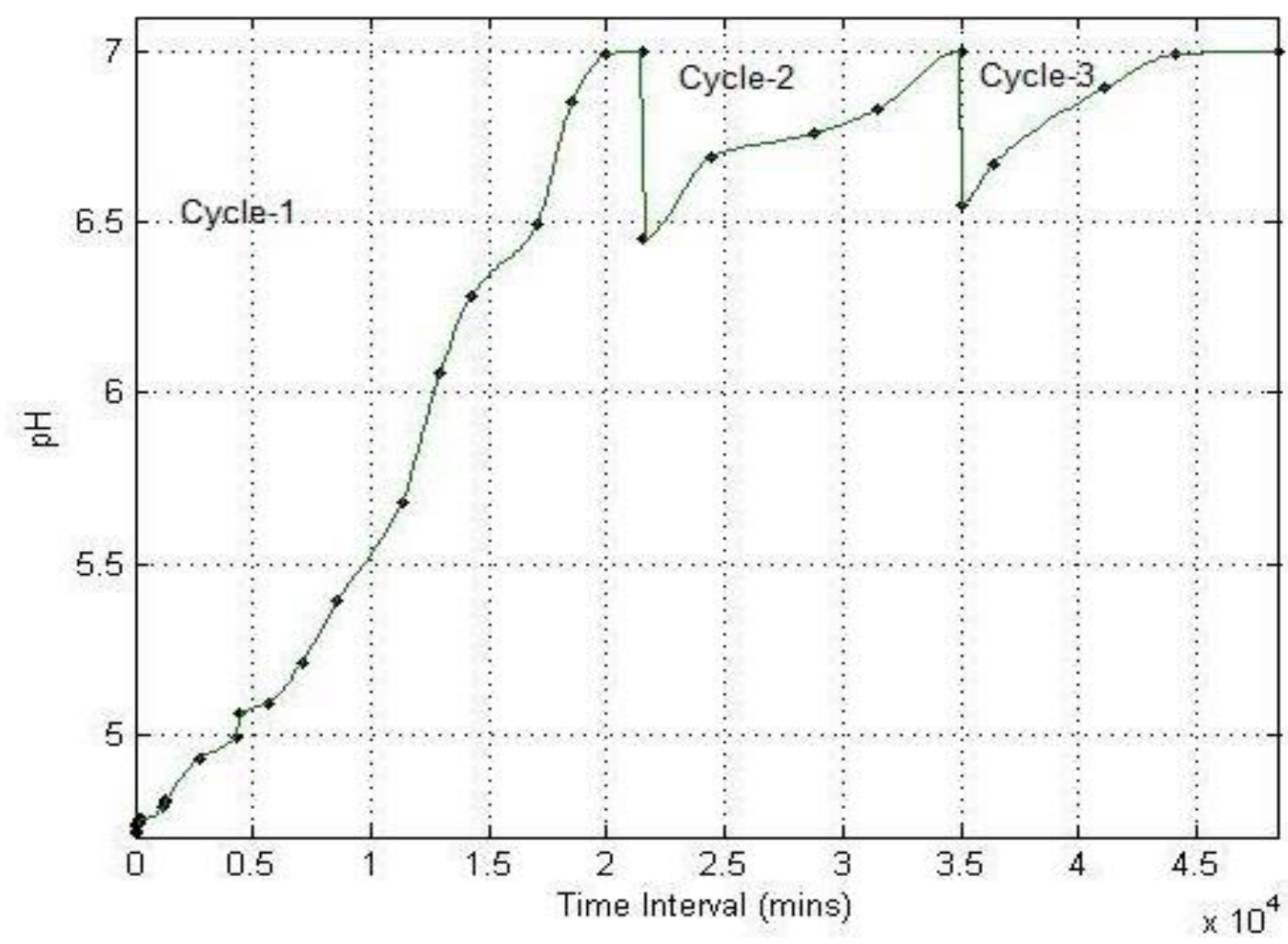

Fig -5: pH Vs Time graph for all three cycles.

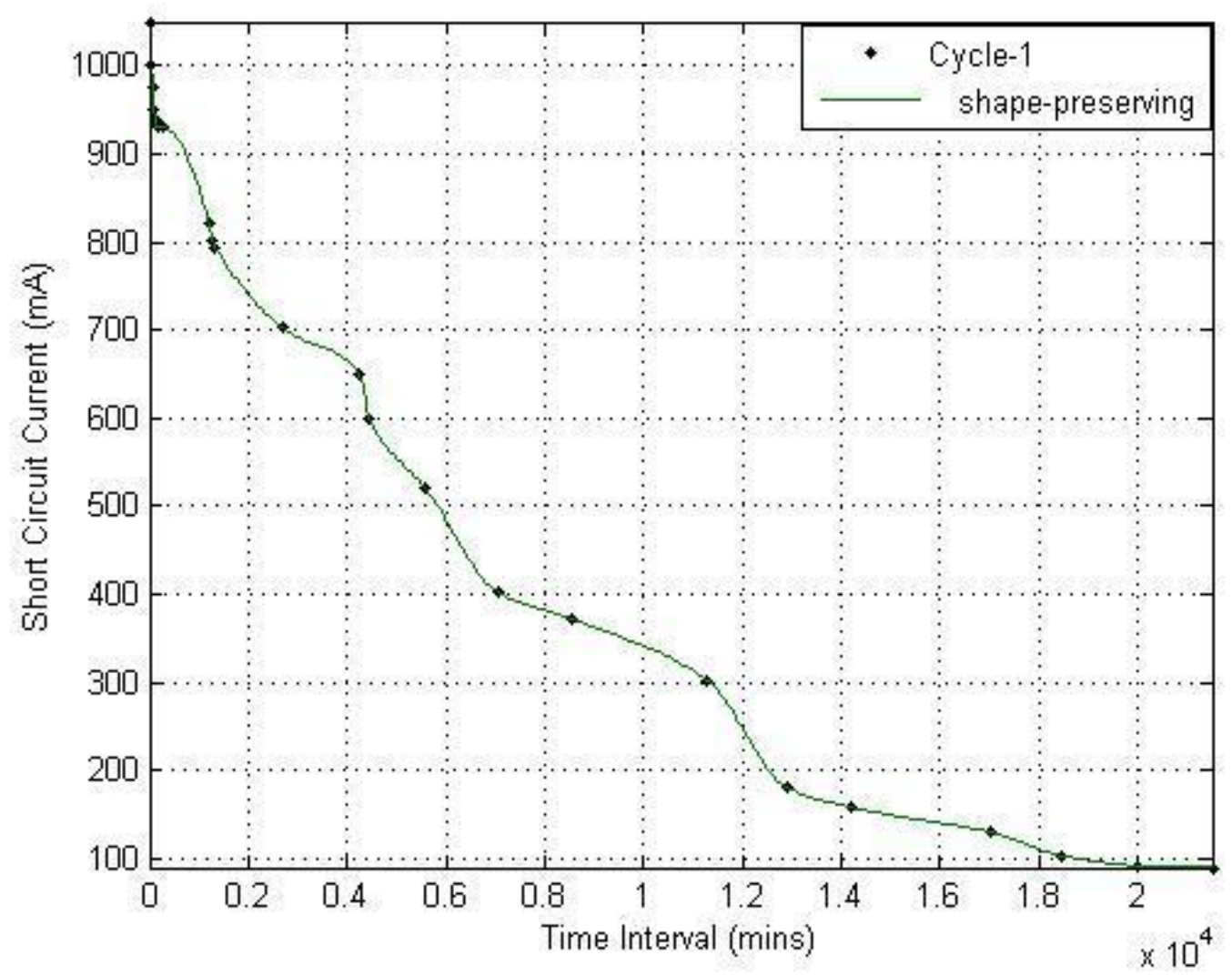

Fig -6: Short Circuit Current Vs Time graph for Cycle-1. 


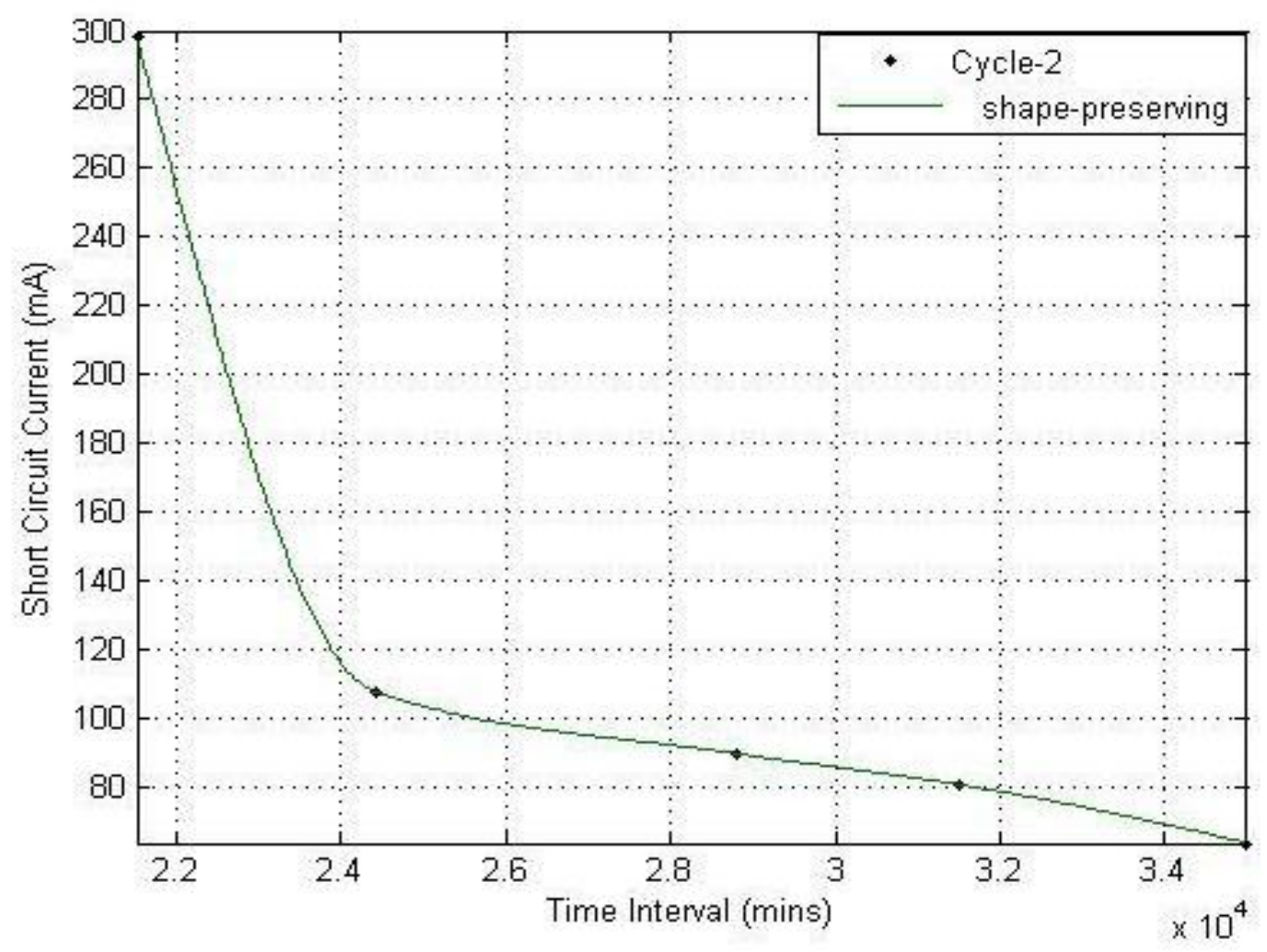

Fig -7: Short Circuit Current Vs Time graph for Cycle-2.

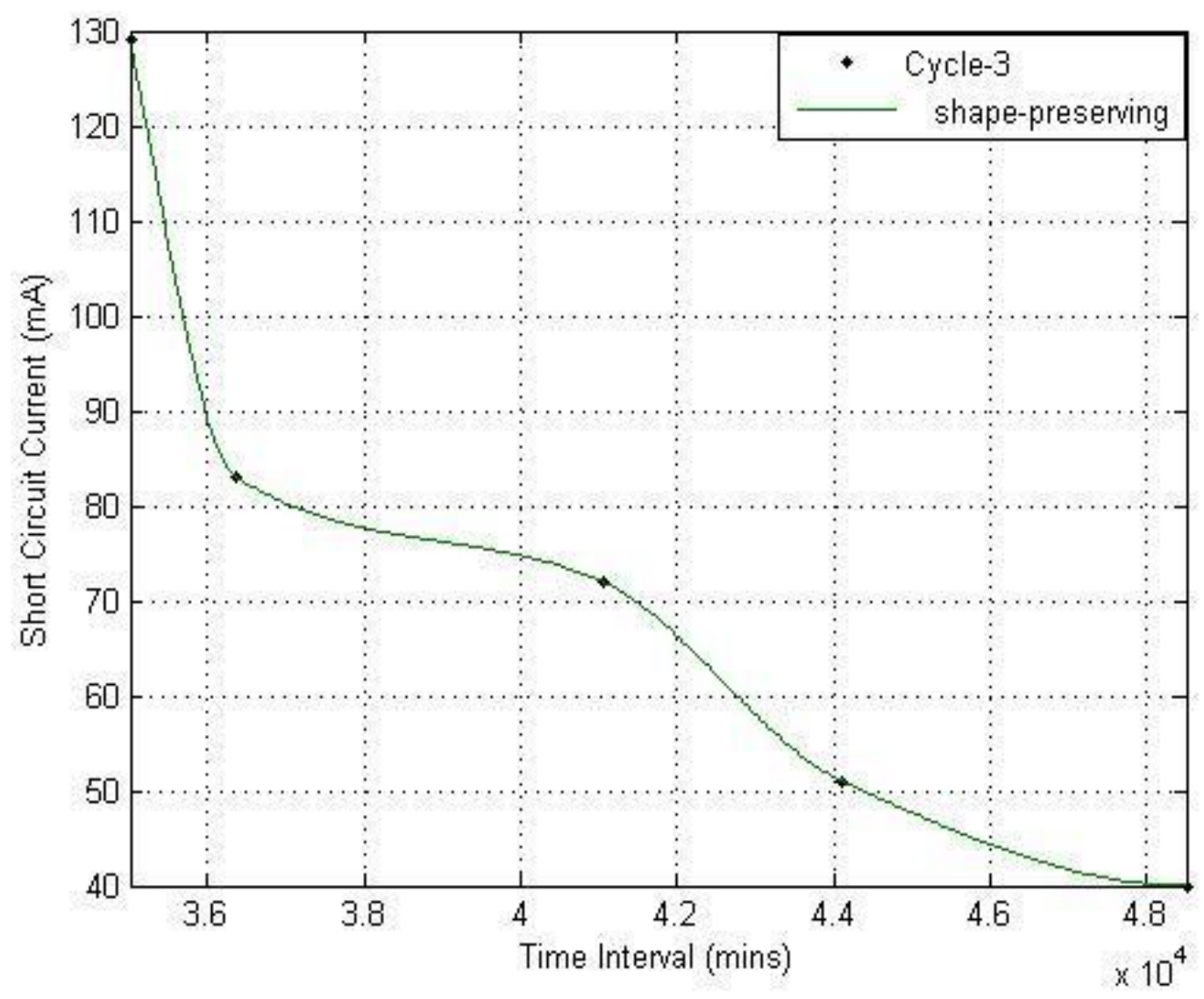

Fig -8: Short Circuit Current Vs Time graph for Cycle-3. 


\section{CONCLUSION}

As a primary cell, the life time to reserve the charge of BPL cell is considered to be average. Here our investigations showed that basically the shelf-life of BPL cell is not much comparable with other types of primary cell because of its reduced life time. The data and figures, given above, validates that both the voltage and current remains almost stable for first few hours and later both the voltage and current decrease quite harshly in the all three cycles and for $\mathrm{pH}$ the occurrence is thoroughly opposite. We can conclude that; the self-discharge rate of BPL cell is high. As both the electrodes are directly in contact with the acidic electrolytesthe sap, the exchange of electrons from the electrolytes and the electrodes occurs rapidly because of the activeness of the electrodes. Thus, due to unwanted chemical actions on the anode the BPL cell loses its energy. A separator may be used to separate the electrodes from dropping the unwanted energy and thus to increase the life-time. The movement in the sap increases the cell performances, can be considered as another outcome of this study. Our study was done on a certain system, and a well variation was observed on our other studies that the BPL cell performance largely depends on the physical and chemical variations of the specimens.

\section{REFERENCES}

[1]. Battery performance characteristics, MPower UK, 23 February 2007. Information on self-discharge characteristics of battery types.

[2]. Wu and White, "Self-Discharge Model of a NickelHydrogen Cell." Journal of the Electrochemical Society, Vol. 147(3), P. 901-909, 2000.

[3].http://batteryuniversity.com/learn/article/elevating_self_ discharge

[4]. DE Okwu and C Josiah,"Evalution of the chemical composition of two Nigerian medicinal plants", African Journal of Biotechnology, Vol. 5, P. 357-361, February 2006.

[5]. A Kamboj, AKSaluja, "Bryophyllum pinnatum (Lam) Kurz.: Phytochemical and Pharmacological Profile: A Review" Pharmacognosy Reviews, Vol. 3 (6), P. 364-374, 2009.

[6]. DA Alabi, MZOnibudo, NA Amusa, "Chemicals and Nutritional Composition of four Botanicals with FungitoxicProperties", World Journal of Agricultural Science, Vol. 1(1), P. 54-88, 2005.

[7]. J Sultana., KA Khan., MU Ahmed. "Electricity Generation from PathorKuchi Leaf (BPL) (Bryophillum pinnatum)." Journal of Asiatic Society, Bangladesh Sci., Vol. 37(4), P. 167-179, December 2011.

[8]. M Hasan, KA Khan, MA Mamun, "An Estimation of the Extractable Electrical Energy from Bryophyllum pinnatum Leaf', American International Journal of Research in Science, Technology, Engineering \& Mathematics (AIJRSTEM), Vol. 1 (19), P. 100-106, 2017.

[9]. MM Hasan, MKA Khan, MNR Khan and MZ Islam, "Sustainable Electricity Generation at the Coastal Areas and the Islands of Bangladesh Using Biomass Resources", City University Journal, Vol. 2 (1), P. 09-13, 2016.
[10]. M Hasan and KA Khan "Bryophyllum pinnatum Leaf Fueled Cell: An Alternate Way of Supplying Electricity at the Off-grid Areas in Bangladesh" in Proceedings of 4th International Conference on the Developments in Renewable Energy Technology [ICDRET 2016], P. 01, 2016.

\section{BIOGRAPHIES}

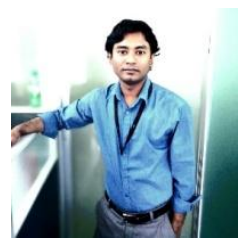

Mehedi Hasan has completed his B.Sc. and M.Sc. in Physics from Jagannath University, and now pursuing M. Phil in Solid State Physics at BUET. He's also a Lecturer at Department of EEE, City University, Bangladesh.

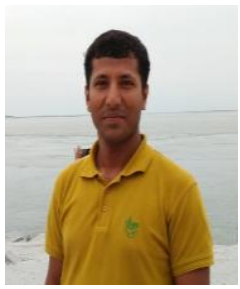

Lovelu Hassan has completed his B.Sc. and M.Sc. in Applied Physics from Islamic University and currently pursuing $\mathrm{PhD}$ at Jahangirnagar University. He's also working as Deputy Manager (Geophysical Division) at BAPEX.

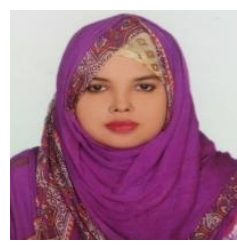

SunjidaHaque has completed her B.Sc. and M.Sc. in Mathematics from Jagannath University, and now pursuing M. Phil. in Inventory Model at there too. She's also a Lecturer at Department of EEE, City University, Bangladesh.

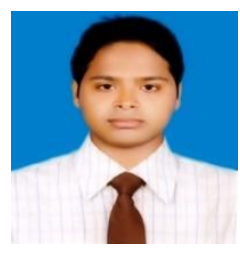

Mizanur Rahman has completed his B.Sc. and M.Sc. in Physics from Jagannath University, andnow he's a $\mathrm{PhD}$ candidate.

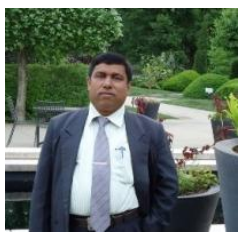

KamrulAlam Khan has completed his B.Sc., M.Sc. and PhD from Dhaka University and is a Professor at Dept. of Physics, Jagannath University, and BD. He has published hundreds of papers and supervised so many M.Sc. M.Phil. and $\mathrm{PhD}$ students. Other authors are still working under his supervision in different research projects. He got some national and international award for his achievements. He has 4 patents. 